\title{
Welcome from the Local Host Committee
}

KNOWN AS THE CROSSROADS OF AMERICA, Indianapolis is within a day's drive of over half of the country's population. This year's conference setting provides an opportunity to share a ride and a room with another member of your library team or to bring your family along.

Situated in the heart of Indy, our conference hotel, the Hyatt Regency, is within walking distance of many top attractions and restaurants. A skywalk connects the hotel to Circle Centre Mall, featuring ninety stores and services.

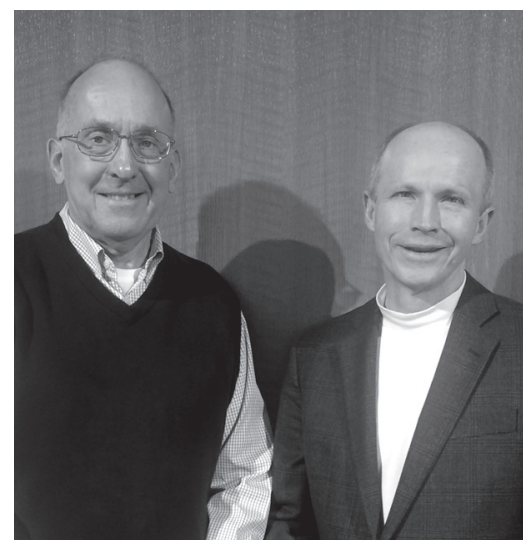

For those traveling with families, the top ten-rated Indianapolis Zoo and White River Gardens is a thirty-minute walk. Both the Indianapolis Children's Museum, the world's biggest and best, and the Indianapolis Motor Speedway and Museum, home of the Indianapolis 500, are a fourteen-minute drive. Further afield, Conner Prairie, a nationally acclaimed history destination and outdoor museum, is a thirty-three-minute drive.

Your local hosts have arranged two opportunities for Indianapolis historic walking tours on Wednesday. Both begin and end in the conference hotel. On Thursday evening, the Indianapolis Indians play the Toledo Mud Hens at Victory Field Stadium, a 10-12-minute walk from the hotel. Recognized as one of the best baseball parks in 
the US, enjoy panoramic views of the downtown Indy skyline from Victory Field.

For Indiana Librarians, Indianapolis is where we make connections. Indy is the hub to which all the roads lead from our seminaries, colleges, and universities scattered throughout the state. We hope your road (or flight) also leads here.

This year's conference invites you to connect at the crossroads of America and to join fellow theological librarians in conversation and creative collaboration about the changing landscape of theological education, theological libraries, and theological scholarship.

We look forward to welcoming you to Indianapolis. Come join us and experience Hoosier hospitality.

Your Local Host Committee Co-chairs, Ken Boyd and Robert Roethemeyer 